\title{
DIMENSIONAL STABILITY AND COLOUR RESPONSES OF Pinus Elliottii WOOD SUBJECTED TO FURFURYLATION TREATMENTS
}

\author{
Andrey Pereira Acosta ${ }^{1}$, Henrique Römer Schulz, Kelvin Techera Barbosa ${ }^{1}$, \\ Gustavo Spiering Zanol, Ezequiel Gallio ${ }^{1}$, Rafael de Avila Delucis ${ }^{1}$, Darci Alberto Gatto ${ }^{1, \star}$
}

\begin{abstract}
Organic substances have been used for different wood treatments, especially impregnation procedures, aiming at improve certain wood properties. The objective of this study was to evaluate dimensional stability and colourimetric features for a mature pine wood (Pinus elliottii) impregnated by vacuum-pressure process with variable concentrations ( $10 \mathrm{wt} \%, 25 \mathrm{wt} \%$ and $50 \mathrm{wt} \%$ ) of furfuryl alcohol and using ethyl alcohol as catalyst. The wood samples were characterized for:linear shrinkages, linear swellings, shrinkage anisotropy, swelling anisotropy, as well as colorimetric parameters (following the CIELab method). The impregnation with furfuryl alcohol increased the dimensional stability of the studied pine wood and the treatment with a concentration of $50 \mathrm{wt} \%$ stood out based on these results. Regarding the colourpatterns, there were changes in the final colorimetric appearances of the treated wood samples, which acquired darker and reddish colours when compared to the pristine group. The treatment with $50 \mathrm{wt} \%$ of furfuryl alcohol also was responsible for the highest colour change and, because of that, may be indicated for solid wood products with high added value.
\end{abstract}

Keywords: Anisotropy, colourimetry, CIELab, dimensional stability, wood colour, furfuryl alcohol.

\section{INTRODUCTION}

Chemical modifications have been applied in solid woods to induce improvements in some of their chemical, hygroscopic and mechanical properties. These wood treatments act in the main macromolecular groups from wood, namely cellulose, hemicellulose and lignin. The main reported wood treatments include: thermal treatments (heating under controlled time, atmosphere, and humidity), formalization (reaction with formaldehyde), and esterification (reaction with acetic anhydride, carboxyl acid, or isocyanate).

In this context, the furfurylation (reaction with furfuryl alcohol (FFA) $-\mathrm{C}_{5} \mathrm{H}_{6} \mathrm{O}_{2}$ ) stands out, especially in Europe, wherein kebony ${ }^{\circledR}$ was developed. This is the most important patent on the furfurylated wood (Gérardin 2016). Besides, FFA is a non-toxic and non-flammable chemical substance. It can be produced from agricultural wastes, like sugar cane and corn cobs (Mantanis 2017). The furfurylated wood contains absolutely nontoxic constituents, its combustion did not release any volatile organic compounds or polyaromatic hydrocarbons above the normal levels for wood combustion and its leachates have shown no significant ecotoxicity (Mantanis 2017).

About the wood performance, according to Magalhães and Da Silva (2004), an aqueous solution of FFA is ideal for a wood treatment, since it presents a low viscosity at room temperature and a fast polymerization when heated at $100^{\circ} \mathrm{C}$. Therefore, this environmentally-friendly treatment has been attracting much attention, since has proven to be capable of induce many improvements in wood performance, including increased dimensional stability (Lande et al. 2004), increased mechanical properties (Dong et al. 2016), increased thermal stability (Dong et al. 2016), decreased flammability (Dong et al. 2016), increased aesthetical value (Dong et al. 2016), as well as increased resistance to both weathering and biodegradation (Ermeydan et al. 2014). 
On the other hand, pine woods have low dimensional stability, low natural durability and low mechanical performance, especially those woods planted in tropical countries, like Brazil. Also, the pine woods present a bright colour, which is considered a poor aesthetical characteristic. Therefore, the impregnation process using FFA seems to be a potential treatment for the improvement of the pine woods performance. In addition, pine woods are cheap, have low density and high permeability, which makes them prone to be efficiently impregnated with preservative solutions, like FFA.

Besides of that, the pine woods are one of the main marketed gender in many temperate countries around the world. For instance, the Pinus elliottii naturally occurs in certain places from North America, Brazil and Australia. Its main applications include furniture, civil construction, and decorative parts. Also, its resin presents a high added value and can be used to produce chemicals applied for varnishes, paints, cosmetics, medicines, among others. Nevertheless, in Brazil, the Pinus elliottii is the most planted specie in both south and southeast, since it presents the fastest growth among all the main available conifers (Schneider et al. 2014).

In addition, 10 years old Pinus elliottii trees are starting to produce mature wood (Trevisan et al. 2014), while most of the other pines only become adult plants after 15-20 years of life (Ballarin and Lara Palma 2003,Vidaurre et al. 2012). It is an important feature, since the mature wood is preferred for the manufacture ofsolid products with high quality (Vidaurre et al. 2012), as those subjected to furfurylation. Also, the Pinus elliottii of ten presents inferior properties when compared to similar pines and, consequently, it must be treated to be properly used (Bao et al. 2001). In this context, the objective of this work was to evaluate hygroscopic and colorimetric properties of a mature Pinus elliottii wood subjected to furfurylation treatments.

\section{MATERIALS AND METHODS}

\section{Raw material selection}

Wood samples with the dimensions of $25 \mathrm{~mm} \times 25 \mathrm{~mm} \times 100 \mathrm{~mm}$ (radial $\times$ tangential $\times$ longitudinal) were cut from wood boards from Pinus elliottii Engelm. trees, which were 20 years old when over turned. Afterwards, the samples were placed into a climatic chamber (adjusted for a temperature of $20^{\circ} \mathrm{C} \pm 2{ }^{\circ} \mathrm{C}$ and a relative humidity of $65 \% \pm 3 \%$ ) until reach constant mass.

\section{Impregnation with FFA}

Four different concentrations of a high purity $(98 \%)$ solution of FFA (with $1,135 \mathrm{~g} \cdot \mathrm{mol}^{-1}$ at $25^{\circ} \mathrm{C}$ ) were impregnated into the woods. The used solutions were composed of four substances: furfuryl alcohol; citric acid (since it has anti-volatilizing and anti-oxidant properties); water (in order to facilitate the overall homogenization); and ethyl alcohol (applied as catalyst). Thus, three solutions were prepared: $\mathrm{T}_{\mathrm{F} 10 \%}$ ) $10 \mathrm{wt} \%$ of FFA, $80 \mathrm{wt} \%$ ethyl alcohol, $5 \mathrm{wt} \%$ of water, and $5 \mathrm{wt} \%$ of citric acid; $\mathrm{T}_{\mathrm{F} 25 \%}$ ) $25 \mathrm{wt} \%$ of FFA, $65 \mathrm{wt} \%$ ethyl alcohol, $5 \mathrm{wt} \%$ of water, and $5 \mathrm{wt} \%$ of citric acid; $\left.\mathrm{T}_{\mathrm{F} 50 \%}\right) 50 \mathrm{wt} \%$ of FFA, $40 \mathrm{wt} \%$ ethyl alcohol, $5 \mathrm{wt} \%$ of water, and 5 wt $\%$ of citric acid.

In the impregnation process, the specimens were placed inside a small horizontal autoclave $(2,3 \mathrm{~L}$ capacity), which was subjected to an initial vacuum of $0,1 \mathrm{MPa}$ for 20 min using a vacuum pump, in order to remove the air from the inside of the wood. The FFA-based solution was poured into the autoclave cavity using the pressure difference caused by the internal vacuum. Then, a positive pressure of $8 \mathrm{MPa}$ was applied for extra $90 \mathrm{~min}$.

After the impregnation step, the samples were put in a laboratory oven having a constant temperature of $70^{\circ} \mathrm{C}$, in order to produce the in situ polymerization of the FFA inside the wood. The final samples were conditioned under room temperature $\left(20^{\circ} \mathrm{C}\right)$, until reach equilibrium moisture content.

\section{Hygroscopic properties of the samples}

The influences of the furfurylation treatments over the shrinkages and swellings of the wood in both tangential and radial planes were measured with a calliper (with $0,0001 \mathrm{~mm}$ resolution). For that, 10 samples by each groups were studied. The radial and tangential dimensions of the waterlogged samples were measured and these values were used in the Equation 1, Equation 2, Equation 3, and Equation 4, to determine both the linear shrinkages and linear swellings. The anisotropy for both the radial and tangential orientations were calculated 
by Equation 5 and Equation 6, using linear shrinkages and linear swellings.

$$
\begin{aligned}
& \beta_{R}=\left(\frac{R_{\max }-R_{0}}{R_{\max }}\right) x 100 \\
& \beta_{T}=\left(\frac{T_{\max }-T_{0}}{T_{\max }}\right) x 100 \\
& \alpha_{R}=\left(\frac{R_{\max }-R_{0}}{R_{0}}\right) x 100 \\
& \alpha_{T}=\left(\frac{T_{\max }-T_{0}}{T_{0}}\right) x 100 \\
& \text { Ca } \beta=\left(\beta_{T} / \beta_{R}\right) \\
& \text { Ca } \alpha=\left(\alpha_{T} / \alpha_{R}\right)
\end{aligned}
$$

Where: $\beta_{\mathrm{R}}$ and $\beta_{\mathrm{T}}$ are radial and tangential linear shrinkages (\%), respectively; $\alpha_{\mathrm{R}}$ and $\alpha_{\mathrm{T}}$ are radial and tangential linear shrinkages (\%), respectively; $\mathrm{Ca} \beta$ is shrinkage anisotropy (\%); Ca $\alpha$ is swelling anisotropy; $\mathrm{R}_{\max }$ and $\mathrm{T}_{\max }$ are waterlogged dimensions $(\mathrm{mm})$ in radial and tangential, respectively; $\mathrm{R}_{0}$ and $\mathrm{T}_{0}$ are oven dried dimensions $(\mathrm{mm})$ in radial and tangential directions, respectively.

\section{Colourimetric analysis of the samples and their morphology}

Six colour reads were taken on each sample, i.e. three on the radial surface and extra three on the tangential surface, for a total of 5 samples per group. This analysis was performed using a CR-400 colorimeter (Konica Minolta brand). The apparatus was configured to use light source (illuminant) D65 and $10^{\circ}$ viewing angle, using the method known as CIELab. The colourimeter reported brightness $\left(\mathrm{L}^{*}\right)$, green-red $\left(\mathrm{a}^{*}\right)$ and blue-yellow $\left(b^{*}\right)$ coordinates, as well as Chroma $\left(\mathrm{C}^{*}\right)$ and hue angle $(\mathrm{h})$, which were used to calculate total colour variation $(\Delta \mathrm{E})$ based on Equation 7. Indeed, the transverse plane of a FFA-treated wood was analysed in a Pro-X SEM microscope (Phenon World brand) to visualize its morphological features.

$$
\Delta E=\sqrt{\Delta L^{* 2}+\Delta a^{*^{2}}+\Delta b^{* 2}}
$$

Where: is total colour variation; is variation in brightness; is variation in green-red coordinate; is variation in blue-yellow coordinate.

\section{Statistical analyses}

The treatments were arranged in a completely randomized design with three concentrations of FFA (10\%, $25 \%$, and $50 \%$ ) plus a control group. The normality of the data and homogeneity of varianceswere verified by the Shapiro-Wilk and White tests, respectively. In case of rejection of the null hypothesis, a Fisher test was performed at $5 \%$ of significance to compare the mean values. 


\section{RESULTS AND DISCUSSION}

The shrinkage levels (as displayed in Table 1) showed that the treatments caused significant reductions for both the radial $\left(\beta_{\mathrm{R}}\right)$ and tangential $\left(\beta_{\mathrm{T}}\right)$ planes, especially the $\mathrm{T}_{\mathrm{F} 10 \%}$ and $\mathrm{T}_{\mathrm{F} 50 \%}$ when compared to that of thecontrol group. However, the shrinkage anisotropy $(\mathrm{Ca} \beta)$ did not present any significant variation in a comparison between the treated samples, although the higher the shrinkage anisotropy $(\mathrm{Ca} \beta)$ was, the higher the percentage of FFA was.

Table 1: Mean values for radial and tangential linear shrinkages, as well as shrinkage anisotropy, of the pine samples.

\begin{tabular}{|c|c|c|c|}
\hline Treatment & $\boldsymbol{\beta}_{\mathbf{R}} \mathbf{( \% )}$ & $\boldsymbol{\beta}_{\mathbf{T}}(\mathbf{\%})$ & $\mathbf{C a} \boldsymbol{\beta} \mathbf{( \% )}$ \\
\hline Control & $4,74 \mathrm{~b}^{(1,358)}$ & $6,30 \mathrm{c}^{(0,236)}$ & $1,43 \mathrm{a}^{(0,286)}$ \\
\hline $\mathrm{T}_{\mathrm{F} 10 \%}$ & $3,82 \mathrm{ab}^{(0,225)}$ & $4,12 \mathrm{ab}^{(1,375)}$ & $1,37 \mathrm{a}^{(0,705)}$ \\
\hline $\mathrm{T}_{\mathrm{F} 25 \%}$ & $4,23 \mathrm{ab}^{(1,722)}$ & $5,72 \mathrm{bc}^{(1,734)}$ & $1,41 \mathrm{a}^{(0,258)}$ \\
\hline $\mathrm{T}_{\mathrm{F} 50 \%}$ & $2,47 \mathrm{a}^{(1,603)}$ & $3,678 \mathrm{a}^{(0,931)}$ & $1,43 \mathrm{a}^{(0,409)}$ \\
\hline $\mathrm{CV}$ & $39,09 \%$ & $32,06 \%$ & $29,49 \%$ \\
\hline $\mathrm{SD}$ & $1,522 \%$ & $1,579 \%$ & $0,415 \%$ \\
\hline $\mathrm{F}$ & $2,12 *$ & $4,61^{*}$ & $0,02 \mathrm{~ns}$ \\
\hline
\end{tabular}

Where: values between parentheses next to the means represent standard deviations and different letters in the columns indicate significant differences according to Fisher tests; $\beta_{\mathrm{R}}$ is radial linear shrinkage; $\beta_{\mathrm{T}}$ is tangential linear shrinkage; $\mathrm{Ca} \beta$ is shrinkage anisotropy; $\mathrm{CV}$ is coefficient of variation; $\mathrm{SD}$ is standard deviation; * is a significant difference at 0,05 of probability of error; $n$ s is a not significant difference.

Mantanis and Lykidis (2015) affirmed that the wood furfurylation leads to a decrease in the equilibrium moisture contentand, consequently,high improves in dimensional stability. This explains the reduction in the linear shrinkage in relation to the analysed planes (Table 2). Also, Esteves et al. (2011) observed a reduction in dimensional stability for a furfurylated Pinus pinaster wood, including the anisotropy, especially due to a high reduction in tangential shrinkage. This is in agreement with the present study, whereas the tangential orientation presented smaller dimensional stability than the radial one. According to Mantanis (2017), the FFA molecules normally penetrate into the wood cell wall, increasing its volume andreducing the amount of free voids able to be filled with water, what leads to an increased dimensional stability.

Table 2: Mean values for radial and tangential linear swellings, as well as swelling anisotropy, of the pine samples.

\begin{tabular}{|c|c|c|c|}
\hline Treatment & $\alpha_{R}(\%)$ & $\alpha_{T}(\%)$ & $\mathrm{Ca \alpha}(\%)$ \\
\hline Control & $5,00 \mathrm{a}^{(1,518)}$ & $6,72 \mathrm{a}^{(0,267)}$ & $1,46 \mathrm{a}^{(0,310)}$ \\
\hline $\mathrm{T}_{\mathrm{F} 10 \%}$ & $3,98 \mathrm{a}^{(0,242)}$ & $3,76 b^{(0,578)}$ & $1,38 \mathrm{a}^{(0,739)}$ \\
\hline $\mathrm{T}_{\mathrm{F} 25 \%}$ & $4,44 a^{(1,882)}$ & $6,09 \mathrm{a}^{(1,946)}$ & $1,43 \mathrm{a}^{(0,274)}$ \\
\hline $\mathrm{T}_{\mathrm{F} 50 \%}$ & $3,02 b^{(0,999)}$ & $3,82 b^{(1,006)}$ & $1,45 \mathrm{a}^{(0,426)}$ \\
\hline $\mathrm{CV}$ & $34,69 \%$ & $34,09 \%$ & $30,50 \%$ \\
\hline SD & $1,450 \%$ & $1,734 \%$ & $1,431 \%$ \\
\hline $\mathrm{F}$ & $1,62^{*}$ & $7,02 *$ & $0,02 \mathrm{~ns}$ \\
\hline
\end{tabular}

Where: values between parentheses next to the means represent standard deviations and different letters in the columns indicate significant differences according to Fisher tests; $\alpha_{\mathrm{R}}$ is radial linear swelling; $\alpha_{\mathrm{T}}$ is tangential linear swelling; $\mathrm{Ca} \beta$ is swelling anisotropy; $\mathrm{CV}$ is coefficient of variation; $\mathrm{SD}$ is standard deviation; * is a significant difference at 0,05 of probability of error; $n$ is a not significant difference.

The FFA-treated woods presented both smaller radial $\left(\alpha_{\mathrm{R}}\right)$ and tangential $\left(\alpha_{\mathrm{T}}\right)$ linear swellings when compared with the control group, and again the impregnations with $10 \%$ and $50 \%$ of FFA stood out. Dong et al. (2016) furfurylated a Pinus massoniana wood using concentrations of $30 \%, 50 \%$ and $70 \%$ of FFA, which were incorporated with maleic anhydride and disodium tetraborate. These authors also reported water absorptions of $8,19 \%, 10,68 \%$, and $10,02 \%$ for the concentrations of $30 \%, 50 \%$ and $70 \%$ of FFA, respectively. These results are larger than those found in the present work. This can be explained by the use of citric acid as an anti-leaching agent, producing a more hydrophobic FFA solution. The FFA-treated woods presented darkened 
colour patterns on both analysed anatomical planes(Figure 1). Based on that, it seems to exist a not fully understood relationship betweenFFA and extractives or lignin, which possibly influenced the final wood colour (Lande et al. 2004).

Figure 2 shows the transverse plane for a $\mathrm{T}_{\mathrm{F} 50 \%}$-treated wood, wherein some morphological effects of the above mentioned not fully understood mechanism can be visualized. The wood cell walls seem to become thicker than the normal. According to Mantanis (2017), the furfural resin polymerizes in cell lumen or attach itself to cell wall forming a thin layer, which seals the lumen surface and, because of that, there is an increase in cell wall thickness. From a chemical standpoint, this mechanism is attributed to an interaction between the FFA and the lignin located at middle lamella and tracheids corners (Yang et al. 2019).



Figure 1: Photographs of both the radial and tangential planes for the pine samples.

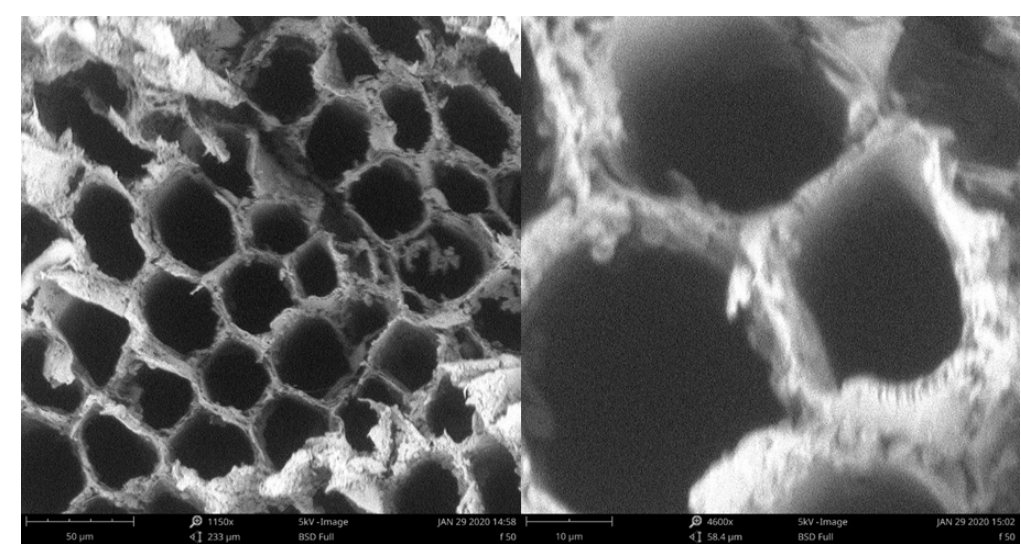

Figure 2: SEM micrographs of the transverse plane for a pine wood treated with $50 \%$ of furfuryl alcohol.

The FFA-treated woods presented smaller brightness $\left(\mathrm{L}^{*}\right)$ for both anatomical planes (tangential and radial) when compared to the control group (Table 3 and Table 4). Still regarding the $L^{*}$, all the treatments presented similar darkened colours. With respect to the green-red coordinate $\left(a^{*}\right)$, there was a gradually increase as the concentration of FFA is increased, thus leading to a predominance of red tones on the surface of the treated woods. In general, a* is closely related to the phenolic compounds of different woods (Mori et al. 2005), which can also indicate a not fully clear chemical change in lignin or an organic extractives belong to the wood.

On the other hand, the blue-yellow coordinate $\left(b^{*}\right)$ of the treated woods significantly changed compared to the control group for both the radial and tangential planes. Theoretically, $\mathrm{b}^{*}$ is associated with organic chro- 
mophores present in extractives and lignin (Pincelli et al. 2012), also indicating a chemical interaction between the wood and the polymerized FFA.

The chroma $\left(\mathrm{C}^{*}\right)$ also significantly increased, while the hue angle $\left(\mathrm{h}^{\circ}\right)$ showed reduced values for the treated woods. The treatment with $50 \%$ FFA stands out based on its $\mathrm{C}^{*}$ levels, which means a high homogenized colour pattern for this treated wood. Regarding the total colour variation $(\Delta \mathrm{E})$, only on the tangential plane there were significant differences between the treated woods. Therefore, all the treatments caused high colour changes on the wood planes, especially on the tangential plane, that became more uniformly coloured. This way, the treatment at $50 \%$ of FFA yielded the darkest wood colour $\left(<\mathrm{L}^{*}\right)$, as well as the highest values for $\mathrm{a}^{*}, \mathrm{~b}^{*}$ and $\mathrm{C}^{*}$.

Table 3: Mean values for colourimetric properties of the pine samples on their tangential plane.

\begin{tabular}{|c|c|c|c|c|c|c|}
\hline Treatment & $\mathbf{L}^{*}$ & $a *$ & $\mathbf{b}^{*}$ & $C^{*}$ & $\mathbf{h}^{\circ}$ & $\Delta \mathbf{E}$ \\
\hline Control & $\begin{array}{c}77,81 \mathrm{c} \\
(4,695)\end{array}$ & $\begin{array}{l}5,54 \mathrm{~b} \\
(2,013)\end{array}$ & $\begin{array}{c}23,27 \mathrm{ab} \\
(2,390)\end{array}$ & $\underset{(2,568)}{23,98 \mathrm{~b}}$ & $\begin{array}{c}76,75 \mathrm{~b} \\
(4,155)\end{array}$ & - \\
\hline $\mathrm{T}_{\mathrm{F} 10 \%}$ & $\underset{(9,852)}{43,32 \mathrm{ab}}$ & $\begin{array}{l}8,69 \mathrm{a} \\
(1,715)\end{array}$ & $\underset{(5,733)}{21,61 \mathrm{bc}}$ & $\begin{array}{c}23,47 \mathrm{~b} \\
(5,984)\end{array}$ & $\underset{(2,896)}{66,61 \mathrm{a}}$ & $\underset{(11,888)}{35,82 \mathrm{ab}}$ \\
\hline $\mathrm{T}_{\mathrm{F} 25 \%}$ & $\underset{(8,653)}{40,57 \mathrm{a}}$ & $\begin{array}{c}9,01 \mathrm{a} \\
(1,943)\end{array}$ & $\underset{(6,458)}{20,50 \mathrm{c}}$ & $\underset{(6,498)}{22,46 \mathrm{~b}}$ & $\begin{array}{l}65,38 \mathrm{a} \\
(4,524)\end{array}$ & $\underset{(8,555)}{39,02 \mathrm{~b}}$ \\
\hline $\mathrm{T}_{\mathrm{F} 50 \%}$ & $\underset{(4,497)}{45,52 \mathrm{~b}}$ & $\begin{array}{c}9,62 \mathrm{a} \\
(0,761)\end{array}$ & $\begin{array}{c}24,99 \mathrm{a} \\
(4,015)\end{array}$ & $\begin{array}{c}27,13 \mathrm{a} \\
(4,241)\end{array}$ & $\begin{array}{c}67,18 \mathrm{a} \\
(2,701)\end{array}$ & $\begin{array}{c}33,74 \mathrm{a} \\
(6,326)\end{array}$ \\
\hline $\mathrm{CV}$ & $32,43 \%$ & $29,07 \%$ & $22,74 \%$ & $21,83 \%$ & $8,46 \%$ & $25,87 \%$ \\
\hline SD & 16,806 & 2,353 & 5,139 & 5,298 & 5,841 & 9,365 \\
\hline$F$ & $170,54^{*}$ & $30,81^{*}$ & $4,80 *$ & $4,74^{*}$ & $60,25^{*}$ & $2,50 *$ \\
\hline
\end{tabular}

Where: values between parentheses next to the means represent standard deviations and different letters in the columns indicate significant differences according to Fisher tests; L* is brightness; $\mathrm{a}^{*}$ is green-red coordinate; is blue-yellow coordinate; $\mathrm{C}^{*}$ is chroma; $\mathrm{h}^{\circ}$ is hue angle; $\Delta \mathrm{E}$ is total colour variation; $\mathrm{CV}$ is coefficient of variation; $\mathrm{SD}$ is standard deviation; * is a significant difference at 0,05 of probability of error; ns is a not significant difference.

Table 4: Mean values for colourimetric properties of the pine samples on their radial plane.

\begin{tabular}{|c|c|c|c|c|c|c|}
\hline Treatment & $\mathbf{L}^{*}$ & $\mathbf{a}^{*}$ & $\mathbf{b}^{*}$ & $\mathbf{C}^{*}$ & $\mathbf{h}^{\mathbf{0}}$ & $\Delta \mathbf{E}$ \\
\hline Control & $\begin{array}{c}79,30 \mathrm{~b} \\
(4,633)\end{array}$ & $\underset{(0,529)}{5,58 \mathrm{a}}$ & $\underset{(1,258)}{21,70 \mathrm{a}}$ & $\underset{(1,557)}{22,45 \mathrm{a}}$ & $\underset{(1,412)}{75,69} \mathrm{a}$ & - \\
\hline $\mathrm{T}_{\mathrm{F} 10 \%}$ & $\begin{array}{c}43,98 \mathrm{a} \\
(7,400)\end{array}$ & $\begin{array}{c}9,43 \mathrm{~b} \\
(1,660)\end{array}$ & $\underset{(5,905)}{22,82 \mathrm{a}}$ & $\underset{(6,237)}{24,92 \mathrm{a}}$ & $\underset{(2,171)}{66,00 \mathrm{~b}}$ & $\begin{array}{c}35,17 \mathrm{a} \\
(9,476)\end{array}$ \\
\hline $\mathrm{T}_{\mathrm{F} 25 \%}$ & $\begin{array}{c}43,81 \mathrm{a} \\
(8,125)\end{array}$ & $\begin{array}{c}9,79 \mathrm{~b} \\
(2,185)\end{array}$ & $\underset{(5,794)}{21,05 \mathrm{a}}$ & $\underset{(5,907)}{23,07 \mathrm{a}}$ & $\underset{(3,400)}{66,04 \mathrm{~b}}$ & $\underset{(8,112)}{38,15} \mathrm{a}$ \\
\hline $\mathrm{T}_{\mathrm{F} 50 \%}$ & $\begin{array}{c}45,90 \mathrm{a} \\
(5,436)\end{array}$ & $\begin{array}{c}10,68 \mathrm{c} \\
(1,547)\end{array}$ & $\underset{(4,433)}{25,48 \mathrm{~b}}$ & $\underset{(4,047)}{27,72 \mathrm{~b}}$ & $\underset{(2,445)}{66,47 \mathrm{~b}}$ & $\begin{array}{c}34,65 \mathrm{a} \\
(7,767)\end{array}$ \\
\hline $\mathrm{CV}$ & $30,93 \%$ & $27,09 \%$ & $21,89 \%$ & $21,10 \%$ & $6,79 \%$ & $23,70 \%$ \\
\hline $\mathrm{SD}$ & 16,520 & 2,457 & 5,000 & 5,184 & 4,631 & 8,531 \\
\hline $\mathrm{F}$ & $210,99 *$ & $43,95 *$ & $4,85 *$ & $6,67 *$ & $90,82 *$ & $1,49 \mathrm{~ns}$ \\
\hline
\end{tabular}

Where: values between parentheses next to the means represent standard deviations and different letters in the columns indicate significant differences according to Fisher tests; $\mathrm{L}^{*}$ is brightness; $\mathrm{a}^{*}$ is green-red coordinate; $\mathrm{b}^{*}$ is blue-yellow coordinate; $\mathrm{C}^{*}$ is chroma; $\mathrm{h}^{\circ}$ is hue angle; $\Delta \mathrm{E}$ is total colour variation; $\mathrm{CV}$ is coefficient of variation; $\mathrm{SD}$ is standard deviation; * is a significant difference at 0,05 of probability of error; ns is a not significant difference. 


\section{CONCLUSIONS}

The furfurylation improved the analysed hygroscopic properties of the Pinus elliottii wood. The above discussed results are in agreement with the already presented results in literature for similar treatments and woods. There were decreased levels for FFA-treated pine woods in both shrinkage and swellingon both radial and tangential planes. Regarding of the colourimetry, all the treatments with FFA yielded modified woods with darkened colour patterns, which means that the treated woods acquired increased a esthetical values. The treatment at $50 \%$ of FFA stood out and may be indicated for the manufacture of solid woods with high added value.

\section{REFERENCES}

Ballarin, A.W.; Palma, H.A.L. 2003. Propriedades de resistência e rigidez da madeira juvenil e adulta de Pinus taeda L. Rev Árvore 27(3): 371-380. http://dx.doi.org/10.1590/S0100-67622003000300014

Bao, F.C.; Jiang, Z.H.; Jiang, X.M.; Lu, X.X.; Luo, X.Q.; Zhang, S.Y. 2001. Differences in wood properties between juvenile wood and mature wood in 10 species grown in China. Wood Sci Technol 35(4): 363-375. http://dx.doi.org/10.1007/s002260100099

Dong, Y.; Qin, Y.; Wang, K.; Yan, Y.; Zhang, S.; Li, J.; Zhang, S. 2016. Assessment of the performance of furfurylated wood and acetylated wood: comparison among four fast-growing wood species. BioResources 11(2): 3679 -3690. http://dx.doi.org/10.15376/biores.11.2.3679-3690

Ermeydan, M.A.; Cabane, E.; Gierlinger, N.; Koetz, J.; Burgert, I. 2014. Improvement of wood material properties via in situ polymerization of styrene into tosylated cell walls. Rsc Adv 4(25): 12981-12988. http://dx.doi.org/10.1039/C4RA00741G

Esteves, B.; Nunes, L.; Pereira, H. 2011. Properties of furfurylated wood (Pinus pinaster). Eur J Wood Wood Prod 69(4): 521-525. http://dx.doi.org/10.1007/s00107-010-0480-4

Gérardin, P.2016. New alternatives for wood preservation based on thermal and chemical modification of wood - A review. Ann For Sci 73: 559-570. http://dx.doi.org/10.1007/s13595-015-0531-4

Lande, S.; Westin, M.; Schneider M.H. 2004. Properties of furfurylated wood. Scand J For Res19(5): 22-30. https://doi.org/10.1080/0282758041001915

Magalhães, W.L.E.; Da Silva, R.R. 2004. Treatment of Caribbean pine by in situ polymerization of styrene and furfuryl alcohol. J Appl Polym Sci 91(3): 1763-1769. https://doi.org/10.1002/app.13252

Mantanis, G.I. 2017. Chemical modification of wood by acetylation or furfurylation: A review of the present scaled-up Technologies. BioResources 12(2): 4478-4489.https://doi.org/10.15376/biores.12.2.Mantanis

Mantanis, G.; Lykidis, C. 2015. Evaluation of weathering of furfurylated wood decks after a 3-year outdoor exposure in Greece. Drvna Ind 66(2): 115-122. https://doi.org/10.5552/drind.2015.1425

Mori, C.L.S.O.; Lima, J.T.; Akira Mori, F.; Trugilho, P.F.; Goncalez, J.C. 2005. Caracterização da cor da madeira de clones de híbridos de Eucalyptus spp. Cerne 11(2): 137-146. https://www.redalyc.org/ pdf/744/74411204.pdf

Pincelli, S.M.; Piedade, A.L.; De Moura, L.F.; Brito, J.O. 2012. Effect of thermal rectification on colors of Eucalyptus saligna and Pinus caribaea woods. Maderas-CiencTecnol 14(2): 239-248.http://dx.doi. org/10.4067/S0718-221X2012000200010

Schneider, P.R.; Elesbão; L.E.G.; Schneider, P.S.P.; Longhi, R.V. 2014. Crescimento em diâmetro do Pinus elliottii e Pinus taeda em áreas arenizadas e degradadas no Oeste do Rio Grande do Sul. Cienc Rural 44(9): 1561-1567. http://dx.doi.org/10.1590/0103-8478cr20130744. 
Trevisan, R.; da Motta, C.I.; Fioresi, T.; Trautenmüller, A.V.; Rabuske, J.E.; Denardi, L. 2014. Idade de segregação do lenho juvenil e adulto para Pinus elliottii Engelm. Cienc Rural 44(4): 634-638. http://dx.doi. org/10.1590/S0103-84782014000400010

Vidaurre, G.B.; Lombardi, L.R.; Oliveira, J.T.D.S.; Arantes, M.D.C. 2012. Lenho juvenil e adulto e as propriedades da madeira. FLORAM 18(4): 469-480. http://dx.doi.org/10.4322/floram.2011.066

Yang, T.; Cao, J.; Ma, E. 2019. How does delignification influence the furfurylation of wood. Ind Crops Prod 135: 91-98. https://doi.org/10.1016/j.indcrop.2019.04.019 